\title{
Achieving Sustainable Economic Development in Nigeria through Financial Inclusion in the Agriculture Sector \\ Michael OB*
}

Department of Accounting, University of Lagos, Nigeria

\begin{abstract}
A major challenge in the agriculture sector in Nigeria is access to finance. Examining whether, increased access to financial services by farmers can bring about sustainable development in Nigeria merits attention. In response, the study adopted survey research design to obtain and analyse the perception of 105 farmers in Ogun State, Nigeria on the subject. It was observed that financial inclusion in the Nigerian agriculture sector can be used to achieve sustainable development. The study recommends the siting of more financial institutions in rural areas and financial discipline, amongst others, as measures to achieve financial inclusion in the agricultural sector.
\end{abstract}

Keywords: Agriculture; Sustainable development; Financial inclusion; Financial institutions

\section{Introduction}

Agriculture used to be the largest contributor to the Gross Domestic Product (GDP) in Nigeria before the 1960 independence; the sector employed the largest number of labour, caused the country to earned foreign currencies, and made the country renown in the international community [1]. With the discovery of mineral oil in the 1970s, oil and gas became the mainstay of the economy, causing attention to shift away from agriculture. Besides the agriculture and oil and gas sectors, other real sectors of the Nigerian economy, such as the manufacturing, building and construction, power and energy, oil and gas, amongst others, have attracted foreign direct investment (FDI), grown remarkably and delivered favourable economic results. One of factors responsible for such growth is the high level of interest and economic activities in these sectors, unlike in agriculture where interest has waned in the course of time, in spite of the favourable natural climatic conditions in Nigeria.

Oyewo and Badejo defined sustainable development as 'the utilization of resources to meet the economic, social and environmental needs of human, such that the interest of the present and future generation is served [2].' Sustainable economic development seeks to meet the economic needs of the present generation without compromising the ability of future generations to meet their own economic need. Agriculture uses natural resources such as water, soil, wind, and biodiversity to meet the needs of man. These resources should be used in such a manner that their future use to sustain the economy is not jeopardised. Considering the growth and development which agriculture has brought to the country in time past, it is desirable to tackle the problems currently bedevilling the sector, in order to reposition it for inclusive sustainable development. One of the major challenges in the agriculture sector is access to finance-a problem financial inclusion seeks to address $[3,4]$.

The Central Bank of Nigeria noted that funding in the Nigerian Agricultural sector is about 2 per cent of total lending by banks unlike 6 per cent in Kenya [5]. The problem of financial inclusion is not peculiar to the agriculture sector but to the Nigerian economy at large. For example, Central Bank of Nigeria noted that about $83.9 \%$ of money in circulation is being circulated outside the formal banking sector [6]. This implies that other sectors seek financial services outside the banking system. Also, Nwankwo and Nwankwo reported the result of a study carried out by Enhancing Financial Innovation and Access, EFInA on access to financial service in Nigeria; 34.9 million $(39.7 \%)$ adults were financially excluded. The focus of this paper, however, is on the agriculture sector [7].
By our reckoning, examining whether increased access to financial services in the agriculture sector will bring about sustainable development in Nigeria merits intellectual discussion. It is these thoughts that have spurred us to provide answer to the research question-can financial inclusion in the Agriculture sector be an effective strategy to achieve sustainable development in Nigeria?

The rest of the paper is structured as follows: the next section presents the review of extant literature on the role that agriculture plays in brings about sustainable economic development, and the problems of financial exclusion in the agriculture sector. The next section explains the research method adopted to carry out the study; this is followed by the analyses of data and discussion of findings. The paper is concluded in the last section on concluding remarks. The final part of the paper, concluding remark section, recapitulates the major points of the study, closing off with some recommendations.

\section{Literature Review}

Financial inclusion connotes access to financial services by members of the public especially the financially disadvantaged [8-10]. Merely having a bank account bares prima facia evidence of financial inclusion; having access to all financial services required is the true test of being included in the formal financial sector.

Ibeachu and Onaolapo and Odetayo posited six types of financial exclusion; (i) physical access exclusion brought about by the inability to physically access banking premises for any reason such as bank branch closures, inaccessible road, etc. [9,10]. (physical access exclusion) (ii) if a customer is considered high risk in terms of loan repayment delinquency during credit assessment (access exclusion). (iii) when a customer cannot meet all conditions required to access loan (condition exclusion). (iv) when the price or cost of loan is high and unaffordable to the customer (price exclusion). (v) where financial products are targeted at some individuals or groups (market exclusion). (vi) where an individual deliberately refuses to seek financial products and services for personal reasons (self-exclusion).

${ }^{*}$ Corresponding author: Michael OB, Department of Accounting, University of Lagos, Nigeria, Tel: +2348060651309; E-mail: meetjidemichael@ymail.com

Received February 03, 2016; Accepted April 12, 2016; Published April 15, 2016

Citation: Michael OB (2016) Achieving Sustainable Economic Development in Nigeria through Financial Inclusion in the Agriculture Sector. J Glob Econ 4: 185 doi:10.4172/2375-4389.1000185

Copyright: () 2016 Michael OB. This is an open-access article distributed under the terms of the Creative Commons Attribution License, which permits unrestricted use, distribution, and reproduction in any medium, provided the original author and source are credited. 
Bruhn and Inessa contended that increased access to financial service and affordable loans affects the economy positively. Exclusion from the formal financial system has been caused by factors such as high borrowing cost, high transaction cost, preference for fund allocation by financial institutions to sectors that yield quick and high returns in the short run; absence of financial services or outlets of financial institutions in certain locations especially the rural areas; inability to open an account with financial institution because of documentation requirements; adequate collateral; high account maintenance charge [11-14]. These are general causes, which applies to all sectors, including the agricultural sector. According to the International Finance Corporation causes specific to the agriculture sector are; perceived high risk, complicated credit appraisal procedure, high transaction cost, and the general lack of understanding of peculiarities in the sectorthis birthed the Nigeria Incentive-Based Risk Management System for Agricultural Lending (NIRSAL) [15]. The NIRSAL is a scheme aimed at fixing problems in the agriculture value chain and providing technical assistance to banks to encourage lending by them to agriculture. Other schemes in time past specifically targeted at improving access to finance in agriculture include the establishment of the Nigerian Bank of Agriculture (transited from the Nigeria Agricultural Cooperative and Rural Development Bank, NACRDB) which is the single largest development finance institution in Nigeria, tasked with the responsibility of catering for the credit needs of the Agricultural sector [1]. Commercial banks in Nigeria are also mandated to lend to Agriculture as one of the preferred sectors of the economy.

The inability to access finance from the formal financial system is responsible for farmers' patronage of the informal sector; cooperative societies being the most popular [16,17]. Farmers have as well contributed to some of the hindrances in accessing credit because of issues bothering on; fund mismanagement and diversion, lack of financial literacy, poor record keeping, failure to repay loan annuity when due, inability to provide collateral, lack lustre in financial attractiveness to banks. In this respect, Oladeebo pointed that over the years, farmers have been found to be insensitive and unresponsive to loan repayments, of which the poor repayments have occasioned liquidity challenges for the bank, and in some extreme cases the outright liquidation of the affected financial institutions [4]. Armah and Park noted that farmers' intransigence to loan repayment has caused banks' refusal to issue further loans [18]. In support, Ojo maintained that $66.99 \%$ of small scale farmers in Nigeria utilize loans for farm operations, while $31.07 \%$ of them divert funds by using it for personal purpose of paying children school fees and medical treatments [19].

Nigeria is rich in natural resources; since independence till date, agriculture has continued to contribute to the development of Nigeria in terms of the significant amount earned from exports of items like groundnuts, cocoa, and oil palm products; employment opportunities; and contribution to national income. The sector's contribution to Gross National Product (GNP) was 60 per cent and 49 per cent in the 1960s and 1970s respectively. The sector still has the potential to contribute more.

In view of the sector's potential to contribute more, Omorogbe, Jelena and Fatima asserted that Nigeria currently has $75 \%$ of land available for agriculture but only $40 \%$ is cultivated; exploiting these resources by engaging in more agricultural activities can be used to further develop the country [20]. This explains the inclusion of agriculture in the seven point agenda of Nigeria's vision 2020, which aims at making the country one of the twenty largest economies in the world by year 2020. Financial exclusion has been identified as one of the problems confronting the sector.
In view of the developmental role which agriculture plays in achieving sustainability, and the need to fully utilise the available natural resources, it is important to address the challenges of funding through financial inclusion in the sector. Stated differently, if Nigeria would achieve sustainable development using agriculture as a means, the sector should be immensely developed. Financial inclusiveness in the agriculture sector should increase agricultural output, thus bringing about economic growth and sustainable development. Ayodele, Obafemi and Ebong, corroborated by Omorogbe, Jelena and Fatima argued that by increasing funding to the agriculture sector, Nigeria can speed up its economic growth and sustainability in the long run $[20,21]$. Okafor observed that financial inclusion accelerates flow of credit to small-scale enterprises because credit creates employment and income to rural dwellers who are usually and deeply involved in agriculture. It is therefore hypothesized that [22]:

H1: Financial inclusion in the Nigerian Agriculture sector can be used to achieve sustainable development.

\section{Research Method}

The study adopted a survey research design, using cluster sampling technique. With questionnaire as the data collection instrument, 20 farmers were selected from each cluster of 7 local government areas in Ogun state, Nigeria, making a total of 140 respondents. It was however 105 copies of the research instrument that were retrieved and analysed. The research instrument captured socio-economic characteristics of respondents such as level of education, size of farm, and length of experience and these variables were used for analysis of respondents' perception. Descriptive statistics such as Mean and standard deviation (SD) of data, and inferential statistics such as the kruskal Walis test and partial correlation were used for analyses.

\section{Analyses and Discussion}

\section{Challenges in accessing loans from financial institutions}

Challenges of accessing finance Table 1 are; high interest rate which makes the loan unaffordable $(M=4.96, S D=0.101)$, lengthy time and elaborate procedures in loan processing $(M=4.93, S D=0.117)$, and high cost of loan processing $(M=4.85, S D=0.120)$. The kruskal-walis $\mathrm{p}$ values for each of these factors; interest rate (.606), loan processing time (.134) and loan-processing time (.211) is greater than 0.05 , meaning that at $5 \%$ significance level, there is no significant difference in the perception of farmers on these factors as barriers to financial inclusion. These probably explain why most farmers prefer to patronize the nonformal financial sector [16].

Lack of confidence in the Agriculture sector in Nigeria by banks ( $M$ $=4.75, S D=1.068, \mathrm{p}=0.001)$ may have been responsible for the general unwillingness to lend to the sector $(M=3.98, S D=0.969, \mathrm{p}=0.034)-$ there is difference in the perception on this though, judging from the $p$ values. Overtime, interest in the Agriculture sector has waned in favour of the Oil and gas sector. Budgetary allocation to Agriculture declined from $1.77 \%$ in 2013 to $1.47 \%$ in 2014 [23]. It may therefore be expected that financial institutions may be interested in financing sectors that are booming and gaining attention, rather than Agriculture. The inability to access financial institutions in remote locations is main stream in the challenges of financial inclusion in the Agriculture sector $(M=3.80, S D$ $=0.120$ ). An inferential analysis of the mean score yielding a $\mathrm{p}$ value of .129 shows that there is no statistically significant difference among farmers' perception in this regard. Farmers carry on their businesses in both rural and urban locations, and as such, it is important for them to access financial services, especially the ones located in rural locations. 
This is another gap which the formal financial institutions are failing to cover, but has provided opportunities for informal fund providers. Proximity of financial institutions to farmers should ordinarily bring benefits such as close-monitoring of fund utilization, financial advisory services, training on financial management, and the provision of other assistance required by farmers. Farmers are supposed to enjoy these benefits emanating from financial institutions if they are to be regarded as being financially included.

Other factors contributing to financial exclusion, attributable to individual farmers, include lacking in the meeting up with the following which are requisite for credit worthiness: collateral $(M=4.65$, $S D=1.068)$; financial records and documents $(M=4.55, S D=0.134)$; financial viability in terms of liquidity, profitability and solvency $(M$ $=3.80, S D=0.702)$; and minimum equity contribution $(M=3.75, S D$ $=1.050$ ). With $\mathrm{p}$ values greater than 0.05 for these factors, we infer that these factors are prevailing hindrances to accessing finance from financial institutions, whatever the size of the farming business.

\section{Challenges in repaying loans from financial institutions}

In Table 2, short repayment period in relation to when farm produce start to yield returns in terms of their realisation $(M=4.82$, $S D=0.181)$, and refusal by financial institutions to elongate repayment period $(M=4.76, S D=0.922)$ put farmers under severe pressure to repay, which they may not be able to meet-up with, thereby creating repayment problems. All farmers agree that these two challenges apply to farmers ( $p$ value of 226 and .608 respectively), irrespective of size of farming business. Investing in agriculture business requires patience because of the waiting time between sowing and reaping. One of the major risks inherent in the farming business is the loss of stocks [24,25]. Stock losses to death, disease or theft may cause financial setback $(M=$ $4.74, S D=0.150$ ), because the affected farmer(s) may not be able to generate sufficient revenue from what is left of the stocks to repay loan $(M=4.65, S D=1.092)$

While farmers agree that stock losses may cause financial setback and adversely affect ability to repay $(p=0.101)$, there is significant difference in their views on the inability to repay loan due to insufficient revenue generation $(p=0.000)$. Large-sized farm businesses may be better positioned to generate revenue to repay loan because of economies of large scale in resource input acquisition and output distribution, reduced production cost per unit, better fund management, employment of skilled labour, and easier access to finance, in comparison to small-sized ones. In essence, the inability to generate sufficient revenue to repay loan may be applicable to mostly small or start-up farming businesses. This is consistent with findings by Ayanda and Ogunsekan that socio-economic characteristics such as farm size affect ability to repay loan [1]. The notion that the loan is a grant that is not repayable $(M=4.53, S D=0.337)$ could cause fund diversion to other non-productive use $(M=4.66, S D=0.260)$, or fund mismanagement $(M=4.69, S D=0.797)$, which ultimately leads to financial challenges in loan repayment. With p values greater than 0.05 for these variables, we infer that farmers do not differ in their perception on these factors as being responsible for difficulties in loan repayments. Again, respondents significantly differ in their perception on lack of proper fund management to be a cause of inability to repay loan $(p=0.039)$; while large-sized farming businesses may have recognised the place of proper fund management in business growth, start-up ones may not.

Overall, inability to repay loan for whatever reason in Table 2 will dissuade banks from advancing further credits to farmers, which shuts them out of the formal financial system.

\section{Government's concern and involvement in addressing finan- cial inclusion challenges}

Farmers' views on how concerned the federal government is about financial inclusion in the Agriculture sector, and the level of government involvement in taking steps to address the problem is captured in Table 3. We used the level of education to analyse differences in views among farmers. Responses on the level of concern were: $5 \%$ for very concerned; $12 \%$ for moderately concerned; $48 \%$ for just concerned and $35 \%$ for not concerned at all. The response is bottom-heavy as an aggregate of $83 \%$ of respondents belong to the just

\begin{tabular}{|c|c|c|c|}
\hline Item & Mean & Std. Dev. & p value ${ }^{*}$ \\
\hline Interest rate is high and unaffordable & 4.96 & 0.101 & 0.606 \\
\hline Loan processing takes a lot of time and process & 4.93 & 0.117 & 0.134 \\
\hline Cost of loan processing is high & 4.85 & 0.120 & 0.211 \\
\hline Lack of confidence by banks in the Agriculture sector & 4.75 & 1.068 & 0.001 \\
\hline Non-availability/Inadequacy of collateral to backup loan & 4.65 & 1.068 & 0.116 \\
\hline Poor/Non-existent financial records/documents for loan & 4.55 & 0.134 & 0.004 \\
\hline General unwillingness of banks to lend to Agriculture sector & 3.98 & 0.969 & .034 \\
\hline Inability to access financial institutions in remote locations & 30.80 & 0.120 & 0.129 \\
\hline Non-financial viability (liquidity, profitability) & 3.80 & 0.702 & 0.093 \\
\hline Inability of farmer to meet minimum equity contribution & 3.75 & 1.050 & 0.119 \\
\hline
\end{tabular}

Table 1: Perception of Farmers on the challenges of accessing loan from financial institutions.

\begin{tabular}{|c|c|c|c|}
\hline Item & Mean & Std. Dev. & p value \\
\hline Repayment period is short relative to when stocks start yield & 4.82 & 0.181 & 0.226 \\
\hline Refusal by financial institution to extend repayment period & 4.76 & 0.922 & 0.608 \\
\hline Stock losses to death, disease or theft cause financial setback & 4.74 & 0.150 & 0.101 \\
\hline Lack of proper fund management & 4.69 & 0.797 & 0.039 \\
\hline Funds diversion by farmers to other non-productive use & 4.66 & 0.260 & 0.284 \\
\hline Inability to generate sufficient revenue to repay loan & 4.65 & 1.092 & 0.000 \\
\hline Notion by farmer that loan is a grant, which is not repayable & 4.53 & 0.337 & 0.331 \\
\hline
\end{tabular}

Table 2: Perception of Farmers on the challenges of repaying loans from financial institutions 
concerned and not concerned at all categories. The not concerned at all response has $\mathrm{p}$ value of .000 , suggesting that farmers differ in their opinion on this. The more educated farmers may be aware of various governmental policies at different times to reinvigorate the sector and this might have influenced to some extent their perception on the level of the government's concerned. Other response-Very Concerned $(\mathrm{p}=$ $0.256)$, moderately concerned $(\mathrm{p}=0.072)$, Just concerned $(\mathrm{p}=0.226)$ each has $p$ values greater than 0.05 , implying no significant difference in perception among farmers. Responses on the level of government involvement in addressing the challenges of financial inclusion were: $11.5 \%$ for moderately involved; $66 \%$ for Just involved; and $22.5 \%$ for Not involved at all. None of the respondents regarded the government to be deeply involved. The response is bottom-heavy as well, considering that an aggregate of $88.5 \%$ respondents belong to the just involved and not involved at all categories.

The just involved response has $\mathrm{p}$ value of .037, suggesting that farmers differ in their opinion on this. The Moderately involved ( $p$ $=0.112)$ and not involved at all $(\mathrm{p}=0.360)$ responses have $\mathrm{p}$ values greater than 0.05 , implying that there is no significant difference in the farmers' opinion, irrespective of education level, on the extent to which government is involved in addressing the financial inclusion challenges of the Agriculture sector.

\section{Perceived outcomes of increased access to finance by farmers}

Inferring from results in Table 4, when more funds are available, farmers will be able to: increase the acquisition of resource input while also reaping the economies of large scale in resource acquisition. Increase in output will also cause farm output to increase, which will bring economies of large scale in output distribution. Greater access to funding would enable farmers to acquire and utilise modernised farming techniques for large- scale production. Producing in large quantities should achieve the following: job creation, poverty reduction, more exportation which helps in earning foreign currency and correcting balance of payment deficits, reduction in food exportation which creates favourable balance of trade. The farmers' income will increase such that loan repayment can be conveniently made, while the government also earns more tax revenue. We analysed perceptual differences among farmers on these outcomes using level of education and length of experience as grouping variables. The $\mathrm{p}$ values for all the variables in Table 4 for both grouping variables are greater than 0.05 , meaning they are unanimously agreed as to the outcomes that will accrue from financial inclusion through increased access to finance in the Agriculture sector.

On the whole, increase in access to finance by farmers should bring about positive changes in the Agriculture sector, and the economy at large.

Correlation result in Table 5, using level of education, size and length of experience as control variables, shows strong, significant and positive relationships among the correlated variables, confirming the interrelatedness of these variables in triggering sustainable development and development. The result also reinforces the synergistic effects which increased access to finance in the Agriculture sector should create.

\section{Test of Hypothesis}

In Table 4 on the perceived outcomes of financial inclusion; all $\mathrm{p}$ values are greater than 0.05 , meaning that at $5 \%$ significance level, there is no statistically significant difference in the perception of farmers on the outcomes of increased access to finance in the Agriculture sector. Also, all the variables of correlation analysis in Table 5 have $p$ values $\leq$ 0.10 , meaning that financial inclusion in the agriculture sector creates intertwined, and systemic benefits. On this basis, we accept the alternate hypothesis (H1) that financial inclusion in the Nigerian Agriculture sector can be used to achieve sustainable development.

\section{Conclusion}

Aside credit schemes and institutional infrastructures put in place to develop the agriculture sector, robust tax incentives-like unrestricted capital allowance, non-restriction in the recoupment of losses, amongst

\begin{tabular}{|c|c|c|c|c|c|}
\hline \multicolumn{3}{|c|}{ Concern about financial inclusion } & \multicolumn{3}{|c|}{ Involvement in addressing challenges } \\
\hline Response & $\%$ & p value* & Response & $\%$ & p value ${ }^{*}$ \\
\hline Very Concerned & 5 & 0.256 & Deeply involved & - & - \\
\hline Moderately concerned & 12 & 0.072 & Moderately involved & 11.5 & 0.112 \\
\hline Just concerned & 48 & 0.226 & Just involved & 66 & 0.037 \\
\hline Not concerned at all & 35 & 0.000 & Not involved at all & 22.5 & 0.360 \\
\hline
\end{tabular}

Table 3: Farmers' perception on the federal government's concern and involvement in addressing financial challenges in the agriculture sector.

\begin{tabular}{|c|c|c|c|}
\hline \multirow[t]{2}{*}{ Item } & \multirow[t]{2}{*}{ Mean } & \multicolumn{2}{|l|}{ p value ${ }^{*}$} \\
\hline & & Education & Experience \\
\hline Increase in output as a result of increase in input & 4.80 & 0.139 & 0.215 \\
\hline Increase in acquisition of resource inputs & 4.86 & 0.987 & 0.601 \\
\hline Economies of large scale in resource input acquisition & 4.82 & 0.111 & 0.175 \\
\hline Economies of large scale in output distribution & 4.82 & 0.521 & 0.194 \\
\hline Job creation & 4.77 & 0.112 & 0.329 \\
\hline Reduction in poverty level & 4.77 & 0.412 & 0.418 \\
\hline Production on large scale for export & 4.36 & 0.139 & 0.213 \\
\hline Production on large scale to reduce food importation & 4.41 & 0.121 & 0.712 \\
\hline Farmers' income increase as a result of production increase & 4.84 & 0.644 & 0.399 \\
\hline Large scale production reduces per unit cost of production & 3.99 & 0.199 & 0.317 \\
\hline Acquisition \& use of modernised farming techniques & 4.80 & 0.173 & 0.333 \\
\hline More tax revenue to government following income increase & 3.96 & 0.101 & 0.238 \\
\hline Generation of sufficient revenue to repay loan & 3.99 & 0.556 & 0.198 \\
\hline
\end{tabular}

Table 4: Farmers' perception on outcomes from increased access to finance in the Nigerian agriculture sector. 


\begin{tabular}{|c|c|c|c|c|c|c|c|}
\hline & & ELS & JOB & FImP & $\operatorname{lnDM}$ & FeXP & TAX \\
\hline \multirow[t]{2}{*}{ ELS } & Correlation & 1 & $0.876^{* *}$ & $0.486^{* * *}$ & $0.786^{* * *}$ & $0.788^{*}$ & $0.604^{*+*}$ \\
\hline & p. value (2-tailed) & & 0.031 & 0.000 & 0.000 & 0.073 & 0.000 \\
\hline \multirow[t]{2}{*}{ JOB } & Correlation & & 1 & $0.648^{* *}$ & $0.439^{* * *}$ & $0.895^{* * *}$ & $0.556^{*}$ \\
\hline & p. value (2-tailed) & & & 0.046 & 0.000 & 0.000 & 0.097 \\
\hline \multirow[t]{2}{*}{ FImP } & Correlation & & & 1 & $0.742^{* * *}$ & $0.904^{*}$ & $0.233^{* * *}$ \\
\hline & p. value (2-tailed) & & & & 0.000 & 0.081 & 0.000 \\
\hline \multirow[t]{2}{*}{ InDM } & Correlation & & & & 1 & $0.527^{* * *}$ & $0.789^{+* *+}$ \\
\hline & p. value (2-tailed) & & & & & 0.000 & 0.000 \\
\hline \multirow[t]{2}{*}{ FeXP } & Correlation & & & & & 1 & $0.827^{* *}$ \\
\hline & p. value (2-tailed) & & & & & & 0.051 \\
\hline \multirow[t]{2}{*}{ TAX } & Correlation & & & & & & 1 \\
\hline & p. value (2-tailed) & & & & & & \\
\hline
\end{tabular}

"*significant at 0.01 level "significant at the 0.05 level "significant at the 0.10 level; ELS: Economies of Large Scale in Production; JOB: JOB Creation; FImP: Decrease in Food importation; InDM: Increase in Disposable Income; FeXP: Increase in Food Export; TAX: Increase in Government Tax Revenue.

Table 5: Partial correlation analyses matrix of perceived outcomes from increased access to finance in the Nigerian agriculture sector.

others- exist to stimulate growth of the sector in Nigeria, but actualizing the benefits from such favourable fiscal policies is heavily dependent on the extent to which one engages in agricultural activities. The scale of operation in agriculture business depends on the availability of capital, which in turn depends on access to finance. Deductively, realising the tax benefits in agriculture business is a function of access to finance.

On the basis of farmers' perception that financial inclusion in the agricultural sector can achieve sustainable development, the challenges of financial inclusion in the sector should be urgently addressed by the siting of more financial institutions in rural areas to make financial services accessible in such locations. This also presents the opportunity to monitor farmers and minimise incidence of fund diversion and subsequent loan delinquency. Financial products which consider farmers' peculiarities (such as type of farming business, stock maturity periods, and farmers' socioeconomic status) should be designed. Such considerations should also guide interest rate fixation and timing of loan repayment. Such measures will increase access to affordable credit to farmers while also checkmating the risk of repayment default. The responsibility for achieving financial inclusion is not entirely that of the government and financial institutions; farmers have their roles to play such as being financially disciplined, proper record-keeping and fund-management, financial literacy, and keeping abreast with developments in the sector. The deregulation of insurance in agriculture business is also recommended; opening up the sector for private sector participation in this regard is expected to do the Nigerian economy some good.

\section{References}

1. Ayanda IF, Ogunsekan O (2012) Farmers' Perception of Repayment of Loans Obtained from Bank of Agriculture, Ogun State, Nigeria. Journal of Agricultural Science 3: 21-27.

2. Oyewo BM, Badejo SO (2014) Sustainable Development Reporting Practices by Nigerian Banks. Mediterranean Journal of Social Sciences 5: 2535-2344.

3. Afolabi JA (2010) Analysis of loan repayment among small-scale farmers in Oyo State, Nigeria. Journal of Social Sciences 22: 115-119.

4. Oladeebo OE (2008) Determinants of loan repayment among small holder farmers in Ogbomosho Agricultural Zone of Oyo State, Nigeria. Nigeria Journal of Social Science 17: 59-62.

5. Central Bank of Nigeria (2011) NIRSAL.

6. Central Bank of Nigeria (2009) Statistical bulletin 18: 36-65.

7. Nwankwo O, Nwankwo N (2014) Sustainability of Financial Inclusion to Rural Dwellers in Nigeria: Problems and Way Forward. Research Journal of Finance and Accounting 5: 24-31.

8. McAteer M (2008) Tackling financial exclusion: Ethical solutions. The Financial Inclusion Centre. Glasgow Caledonian University, Scotland.
9. Ibeachu EH (2010) Comparative analysis of financial inclusion: A study of Nigeria and the UK. International Business Leeds Metropolitan University.

10. Onaolapo AA, Odetayo TA (2012) Financial Inclusion as Tools for Survival in Globally Competitive Environment: Lessons for Nigerian Microfinance Banks. American Journal of Business and Management 1: 241-247.

11. Bruhn M, Inessa L (2009) The economic impact of banking the un-banked: evidence from Mexico. World Bank Policy Research working paper.

12. Kempson E (2006) Policy level response to financial exclusion in developed economies: Lessons from developing countries. Access to Finance: Building Inclusive.

13. Oyewo BM, Oyewole OS (2014) Financial System, Financial Inclusion and Economic development in Nigeria. International Journal of Management Sciences 2: 139-148.

14. Masroor AB (2012) Financial Inclusion: Gateway for poverty and unemployment

15. International Finance Corporation (2012) Innovative Agricultural SME Finance models.

16. Adebayo OO, Adeola RG (2008) Sources and uses of agricultural credit by small scale farmers in Surulere Local Government Area of Oyo State, Nigeria. Anthropologist 10: 313-314

17. Badewole O (2011) Developments in the banking system in Nigeria. Central Bank of Nigeria.

18. Armah B, Park TA (1998) Agricultural Bank Efficiency and the Role of Managerial Risk Preference. American Agricultural Economics Association.

19. Ojo MO (1998) Some implications of government economic policies for the financing and development of agriculture in Nigeria. In: Okorie A, ljere MO (eds.). Readings in Agricultural Finance. Longman, Nigeria.

20. Omorogbe O, Jelena Z, Fatima A (2014) The role of agriculture in the economic development of Nigeria. European Scientific Journal 10: 133-147.

21. Ayodele OS, Obafemi FN, Ebong FS (2013) Challenges facing the achievement of the Nigeria vision. Global Advanced Research Journal of Social Sciences 27: 143-157.

22. Okafor FO (2012) Financial Inclusion: An Instrument for Economic Growth and Balanced Development in Rural Areas. Journal of the Chartered Institute of Bankers of Nigeria 6: 38-45.

23. Federal Government of Nigeria (2014) Budgetary allocation.

24. Kahan D (2008) Managing risk in farming

25. Harwood J, Heifner R., Coble K, Perry J, Somwaru A (1999) Managing Risk in Farming: Concepts, Research, and Analysis. Economic Research Service, USDA 